KONSTAN
JURNAL FISIKA DAN PENDIDIKAN FISIKA
Volume 6, Nomor 1, Juni 2021
$\begin{array}{r}\text { E-ISSN : 2460-9129 dan P-ISSN : 2460-9110 } \\ \text { http://jurnalkonstan.ac.id/index.php/jurnal }\end{array}$

\title{
Metode Geolistrik Tahanan Jenis untuk Eksplorasi Air Tanah di Gunung Tunak
}

\author{
Muhammad Zuhdi ${ }^{1}$, Agus Wachid Habiburrahman ${ }^{2)}$ \\ 1)Program Studi Pendidikan Fisika, FKIP, Universitas Mataram, Jl. Majapahit no.62, Mataram, Lombok, \\ Indonesia \\ ${ }^{2)}$ Laboratorium Fisika Dasar, Universitas Mataram. Jl. Majapahit no.62, Mataram, Lombok, Indonesia \\ *E-mail korespondensi: mzuhdi@unram.ac.id
}

\begin{abstract}
Info Artikel: Abstract
Dikirim:

8 Maret 2021

Revisi:

14 April 2021

Diterima:

17 Mei 2021

Geoelectricity is a geophysical method that conducted by injecting an electric current into the earth's interior. This study objected to map aquifer aquifers using the geoelectric method with a Schlumberger electrode configuration consisting of 4 sounding points. The measurement results are then processed with IP2WIN software which produces a real resistivity map as a function of depth. The correlation between sounding points produces a three-dimensional real resistivity map. The results of the study located at Gunung Tunak, Lombok, West Nusa Tenggara, which consists of 4 sounding points show that the aquifer is at a depth of 66.7 meters 31, 2 meters 58, 7 meters and 34, 1 meter respectively,

Kata Kunci: which are displayed comprehensively with 3 dimensional lithology map.
\end{abstract}

Geolistrik,

Schlumberger, Air

Tanah

(C) 2021 Universitas Islam Negeri Mataram

\section{PENDAHULUAN}

Gunung Tunak merupakan daerah wisata pantai yang sedang berkembang. Ketersediaan air bersih terutama yang bersifat tawar belum tersedia di tempat ini. Pengeboran tanpa planning yang tepat akan sia-sia jika hasilnya tidak seperti yang diharapkan, misalnya air bersifat payau atau tidak ditemukan air sama sekali. Padahal keberdaan air tawar sangat di butuhkan oleh penyelenggara wisata di daerah ini. Unruk mengindari resiko tersebut maka dilakukan ekplorasi air tanah menggunakan geolistrik.

Air tanah merupakan air yang terdapat di bawah permukaan tanah yang terdapat pada batuan akuifer. Karakteristik utama yang membedakan air tanah dari air permukaan adalah pergerakan yang sangat lambat dan waktu tinggal yang sangat lama. Durasi ini dapat mencapai puluhan hingga ratusan tahun. Air tanah dapat dibedakan menjadi dua jenis, yaitu air tanah tidak tertekan (free) dan air tanah tertekan (compressed). Air tanah bebas adalah air tanah dari akuifer yang hanya sebagian terisi air, dan terletak pada suatu dasar yang kedap air, dan mempunyai permukaan bebas. Air tanah tertekan (compressed aquifer) adalah air tanah dari akuifer yang sepenuhnya jenuh air, dengan bagian atas dan bawah dibatasi oleh lapisan yang kedap air [1].

Metode Geofisika merupakan metode yang digunakan untuk mempelajari bagian dalam bumi dengan menggunakan pengukuran fisik pada permukaan atau di bawah permukaan bumi. Metode geolistrik merupakan salah satu metode geofisika yang mempelajari sifat fisik di bawah permukaan bumi menggunakan aliran listrik yang dilewatkan di dalam bumi, sehingga didapatkan informasi geologi bawah permukaan melalui sifat fisik kelistrikannya. Ada beberapa macam aturan / konfigurasi pendugaan lapisan bawah permukaan tanah dengan geolistrik ini, antara lain : Wenner, Schlumberger, dipole-dipole dan lain sebagainya. Prosedur pengukuran untuk masing-masing konfigurasi bergantung 
pada variasi resistivitas terhadap kedalaman yaitu pada arah vertikal (sounding) atau arah horizontal (mapping). Metode geolistrik biasanya juga digunakan untuk survey awal sebelum eksplorasi lanjutan dilakukan.

Eksplorasi air tanah menggunakan metode geolistrik telah dilakukan banyak peneliti sebelumnya sebagai metode yang andal dan tepat. Hasibuan, dkk, 2013, melakukan studi intrusi air laut dengan menggunakan metode resistivitas listrik konfigurasi Wenner-Schlumber [2]. Asfiannisa, dkk., 2015, melakukan pendugaan intrusi air laut dalam persiapan pengeboran sumur dalam dengan metode geolistrik 2d dengan menggunakan konfigurasi elektroda Wenner [3]. Irham, M., dkk.,. 2006, melakukan pemetaan sebaran air tanah asin pada aquifer dalam di wilayah Semarang Bawah [4]. Husni, dan Roh, 2012, menyelidiki penurunan muka air tanah dan prediksi intrusi air laut di Kota Tangerang Selatan[5]. Ratnakumari, dkk , 2012. 2D memetakan akuifer di dasar sungai Chandrabhaga, Nagpur District, Maharashtar, India [6]. Sadjab, dkk., 2012. Melakukan pemetaan akuifer air tanah dengan geolistrik di Kecamatan Prambanan Kabupaten Sleman Daerah Istimewa Yogyakarta [7]. Sedana D., dkk.,., 2015. melakukuan pemetaan akuifer air tanah dengan metode geolistrik di Kelurahan Malendeng [8]. Sedangkan Andriayani dkk., 2010, menggunakan metode geolistrik imaging konfigurasi dipole-dipole untuk penelusuran sistem sungai bawah tanah pada kawasan Karst Di Pacitan, Jawa Timur [9].

Pada penelitian ini metode geolistrik yang digunakan adalah Metode Resistivitas Sounding 1D pada empat titik pengukuran, kemudian dilakukan gridding untuk mendapatkan model 2D dan 3D untuk mencari lapisan akuifer air tanah. Pengukuran resitivitas suatu titik sounding dilakukan dengan jalan mengubah jarak electrode mulai dari jarak electrode kecil kemudian membesar secara gradual. Jarak antar elektrode ini sebanding dengan kedalaman lapisan batuan yang terdeteksi. Semakin besar jarak bentangan elektrode, maka semakin dalam lapisan batuan yang dapat terdeteksi. Interpretasi data resistivitas didasarkan pada asumsi bahwa bumi terdiri dari lapisan-lapisan tanah dengan ketebalan tertentu. Metode resistivitas ini merupakan metode yang tepat digunakan untuk eksplorasi air tanah karena sifat resistivitas batuan yang nilainya dipengaruhi oleh kandungan airnya, dan resistivitas kandungan air ini berhubungan dengan kandungan ion-ion di dalamnya.

Dalam survey ini, Pengukuran dilakukan dengan menggunakan 4 buah elektroda, yakni 2 elektroda arus untuk menginjeksikan arus ke dalam bumi dan 2 elektroda potensial untuk mengukur tegangan responnya. Data hasil pengukuran berupa kuat arus dan beda potensial yang telah didapatkan lalu diolah menggunakan software IP2Win untuk mendapatkan grafik 1D dan rockwork 15 untuk mendapatkan model 2D dan 3D.

Hasil yang didapatkan dari penelitian ini adalah informasi posisi atau letak material geologi dalam hal ini berupa air tanah yang ada di area survey berupa model 1D, 2D, dan 3D dari data geolistrik konfigurasi schlumberger. Informasi ini kemudian digunakan untuk mengetahui pola lapisan akuifer air tanah bawah permukaan dan digunakan untuk menentukan lokasi pengeboran air tanah dengan tepat.

\section{METODE PENELITIAN}

Penggunaan geolistrik pertama kali dilakukan oleh Conrad Schlumberger pada tahun 1912. Geolistrik merupakan salah satu metoda geofisika untuk mengetahui perubahan tahanan jenis lapisan batuan di bawah permukaan tanah dengan cara mengalirkan arus listrik DC ('Direct Current') yang mempunyai tegangan tinggi ke dalam tanah. Injeksi arus listrik ini menggunakan 'Elektroda Arus' yang ditancapkan ke dalam tanah pada jarak tertentu. Semakin panjang jarak elektroda arus, akan menyebabkan aliran arus listrik bisa menembus lapisan batuan lebih dalam. Dengan adanya aliran arus listrik tersebut maka akan menimbulkan tegangan listrik di dalam tanah. Tegangan listrik yang terjadi di permukaan tanah diukur dengan penggunakan multimeter yang terhubung melalui elektroda tegangan yang jaraknya lebih pendek dari pada jarak elektroda arus. Bila posisi jarak elektroda arus diubah menjadi lebih besar maka tegangan listrik yang terjadi pada elektroda potensial ikut berubah sesuai dengan informasi jenis batuan yang ikut terinjeksi arus listrik pada kedalaman yang lebih besar (Anonim $\left.{ }^{1}, 2010\right)$.

Umumnya metoda geolistrik yang sering digunakan adalah yang menggunakan 4 buah elektroda yang terletak dalamsatu garis lurus serta simetris terhadap titik tengah, yaitu 2 buah elektroda arus 
(AB) di bagian luar dan 2 buah elektroda tegangan (MN) di bagian dalam. Dengan asumsi bahwa kedalaman lapisan batuan yang bisa ditembus oleh arus listrik ini sama dengan separuh dari jarak elektroda arus (yang dimisalkan dengan elektroda arus A dan elektroda arus B) dapat bernilai AB/2 (apabila digunakan arus listrik DC murni). Sehingga dapat diperkirakan pengaruh dari injeksi aliran arus listrik ini berbentuk setengah bola dengan jari-jari $\mathrm{AB} / 2$ [10]. Prosedur pengukuran untuk masing-masing konfigurasi bergantung pada variasi resistivitas terhadap kedalaman yaitu pada arah vertikal (sounding) atau arah lateral (mapping) [11].

Kombinasi dari jarak $\mathrm{AB} / 2$, jarak $\mathrm{MN} / 2$, besarnya arus listrik yang dialirkan serta tegangan listrik yang terjadi akan didapat suatu harga tahanan jenis semu ('Apparent Resistivity'). Disebut tahanan jenis semu karena tahanan jenis yang terhitung tersebut merupakan gabungan dari banyak lapisan batuan di bawah permukaan yang dilalui arus listrik. Bila satu set hasil pengukuran tahanan jenis semu dari jarak $\mathrm{AB}$ terpendek sampai yang terpanjang tersebut digambarkan pada grafik logaritma ganda dengan jarak $\mathrm{AB} / 2$ sebagai sumbu-X dan tahanan jenis semu sebagai sumbu $\mathrm{Y}$, maka akan didapat suatu bentuk kurva data geolistrik. Dari kurva data tersebut bisa dihitung dan diduga sifat lapisan batuan di bawah permukaan menggunakan kurva bantu sebagai acuan untuk mencari resisitivitas dan kedalaman target penelitian.

Pada konfigurasi Schlumberger idealnya jarak MN dibuat sekecil-kecilnya, sehingga jarak MN secara teoritis tidak berubah. Tetapi karena keterbatasan kepekaan alat ukur, maka ketika jarak AB sudah relatif besar maka jarak MN hendaknya dirubah. Perubahan jarak MN hendaknya tidak lebih besar dari $1 / 5$ jarak AB. Kelebihan dari konfigurasi Schlumberger ini adalah kemampuan untuk mendeteksi adanya non-homogenitas lapisan batuan pada permukaan, yaitu dengan membandingkan nilai resistivitas semu ketika terjadi perubahan jarak elektroda MN/2. Agar pembacaan tegangan pada elektroda MN bisa dipercaya, maka ketika jarak $\mathrm{AB}$ relatif besar hendaknya jarak elektroda MN juga diperbesar [12].

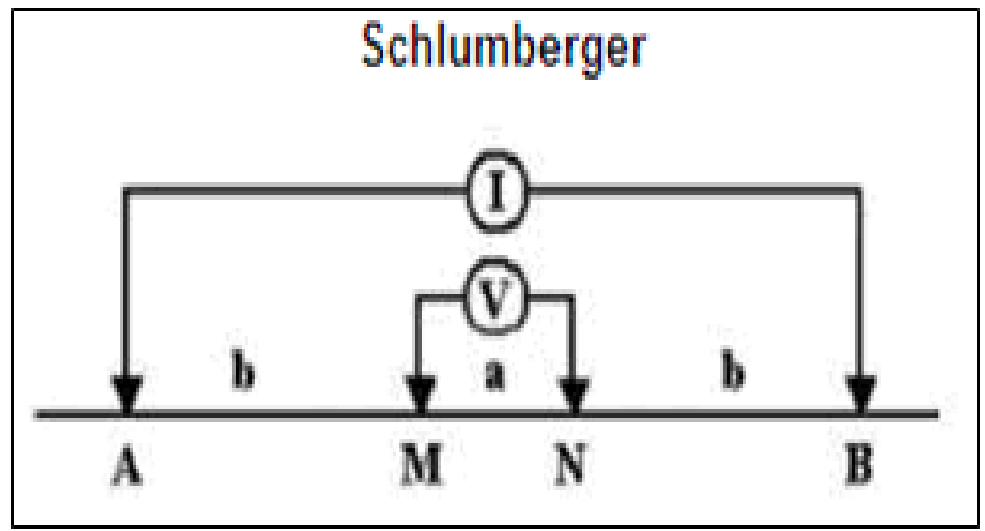

Gambar 1. Konfigurasi Schlumberger

Untuk mencari resistivitas semu (@) dapat menggunakan persamaan :

$$
\rho=K \frac{V}{I}
$$

Dengan $V$ adalah nilai tegangan, $I$ adalah nilai kuat arus yang terbaca pada alat resistivitymeter dan $\mathrm{K}$ adalah faktor geometri untuk konfigurasi elektroda Schlumberger. Nilai K dapat ditentukan dengan persamaan :

$$
K=\frac{\pi(A B / 2)^{2}}{2(M N / 2)}
$$

Metode resistivitas dengan konfigurasi Schlumberger dilakukan dengan cara mengkondisikan spasi antar elektrode potensial adalah tetap sedangkan spasi antar elektrode arus berubah secara bertahap [13].

Akuifer adalah lapisan batuan dibawah permukaan tanah yang mengandung air dan dapat dirembesi air karena porositasnya. Akuifer adalah formasi geologi atau grup formasi yang mengandung air dan secara signifikan mampu mengalirkan air melalui kondisi alaminya. Terminologi 
lain yang digunakan adalah reservoir air tanah atau lapisan pembawa air. Todd (1980) menyatakan bahwa akuifer berasal dari Bahasa Latin yaitu aqui dari aqua yang berarti air dan ferre yang berarti membawa, jadi akuifer adalah lapisan pembawa air [14]. Air tanah adalah air yang bergerak di dalam tanah yang terdapat didalam ruang antar butir-butir tanah yang meresap ke dalam tanah dan bergabung membentuk lapisan tanah yang disebut akuifer. Lapisan yang mudah dilalui oleh air tanah disebut lapisan permeable, seperti lapisan yang terdapat pada pasir atau kerikil, sedangkan lapisan yang sulit dilalui air tanah disebut lapisan impermeable, seperti lapisan lempung dan lanau.

Akuisisi data geolistrik pada penelitian ini dilaksanakan pada Senin-Selasa, 9- 10 April 2018, dengan posisi akuifer terduga berada di Desa Mertak, Kecamatan Pujut, Kabupaten Lombok Tengah, Nusa Tenggara Barat. Alat dan bahan yang dibutuhkan untuk akuisisi data geolistrik antara lain resistivitymeter, kabel rol, rol meter, batang elektroda, alat komunikasi HT dan alat penentu posisi berupa GPS.

Metodologi yang dipakai dalam penelitian ini adalah dengan melakukan akuisisi data geolistrik (pengambilan data primer) dengan elektroda Schlumberger, di lapangan untuk mendapatkan data arus dan beda potensial yang nantinya akan digunakan untuk menentukan harga tahanan jenis. Berdasarkan kisaran harga tahanan jenis tesebut, maka dapat diketahui variasi litologi, ketebalan kisaran harga tahanan jenis tersebut ada atau tidaknya akuifer tanah. Pengambilan data dilakukan pada 4 titik pengukuran di lokasi pengukuran.

\section{HASIL DAN PEMBAHASAN}

Berdasarkan hasil akuisisi data di lapangan dengan menggunakan konfigurasi Schlumberger, yang kemudian dilakukan pengolahan data menggunakan software IP2WIN dan Rockwork 15, maka didapatkan informasi nilai tahanan jenis nyata, kedalaman dan ketebalan lapisan bawah permukaan tanah. Lokasi dan posisi titik sounding akuisisi data geolistrik ditunjukkan pada Gambar 2. Tabel 1 menunjukkan data titik sounding, koordinat dalam UTM dan elevasi dalam meter diukur dari permukaan laut rerata.

Table 1. Lokasi titik survey geolistrik

\begin{tabular}{cccc} 
No & Titik Sounding & Koordinat (UTM) & Elevasi(m) \\
\hline 1 & TITIK 1 & 431036,9011602 & 13 \\
2 & TITIK 2 & 431082,9011543 & 27 \\
3 & TITIK 3 & 431052,9011509 & 17 \\
4 & TITIK 4 & 431136,9011130 & 16 \\
\hline
\end{tabular}

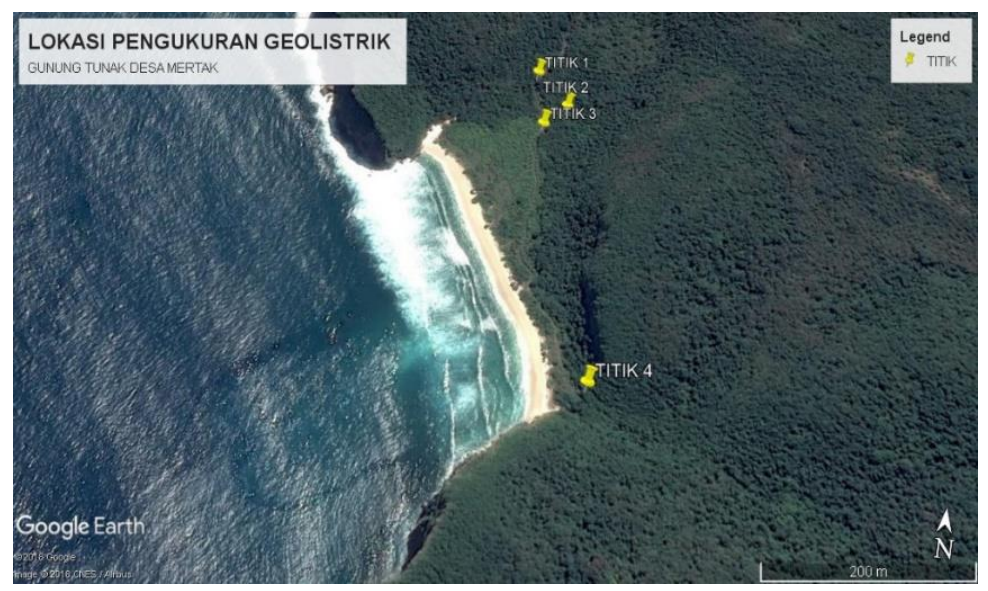

Gambar 2. Lokasi Survey Geolistrik

Gambar 3a, 3b, 3c dan 3d masing-masing menunjukkan hasil pengolahan data geolistrik 1D menggunakan software IP2WIN untuk titik pengukuran 1, titik pengukuran 2, titik pengukuran 3, titik pengukuran 4. Gambar tersebut menunjukkan hasil perhitungan inversi yang dilakukan oleh program 
pada software IP2WIN. Garis biru merupakan nilai resistivitas nyata dari tiap perlapisan, garis merah adalah perhitungan resistivitas semu teoritis hasil inversi sedangkan titik bulat merupakan nilai resistivitas semu hasil pengukuran di lapangan. Perlu diperhatikan bahwa grafik tersebut merupakan grafik logaritmis pada kedua sumbunya. Dari data hasil inversi tersebut kemudian dilakukan korelasi antar titik sounding sehingga didapatkan penampang 2 dimensi untuk minimal korelasi dua buah titik. Gambar 4 menunjukkan hasil korelasi dari keempat titik pengukuran, yaitu titik 1, 2, 3 dan 4 . Interpolasi dari software tersebut menghasilkan nilai peta resistivitas nyata 3 dimensi sebagaimana ditunjukkan oleh gambar 5 .

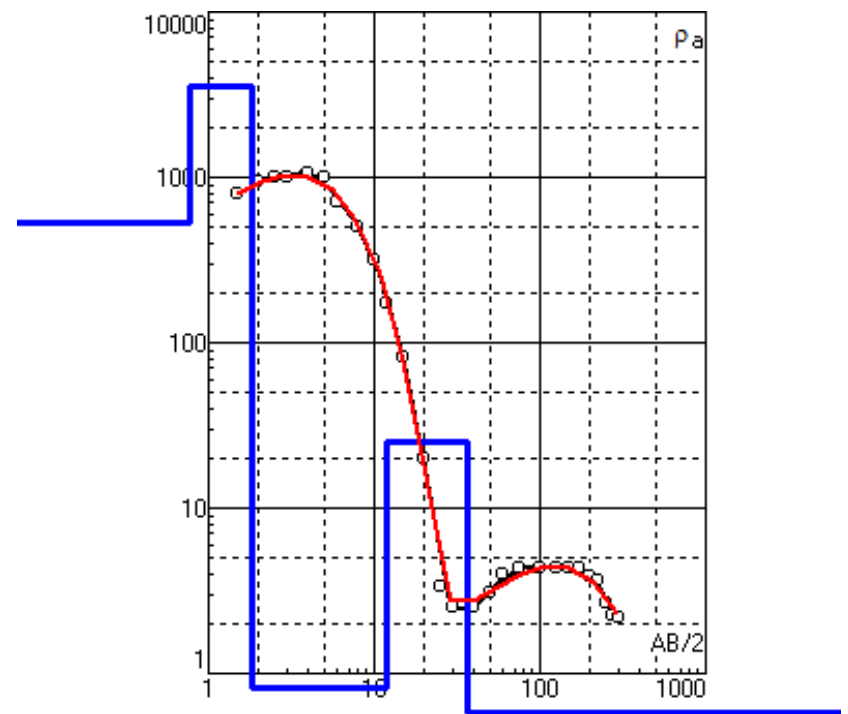

(a)

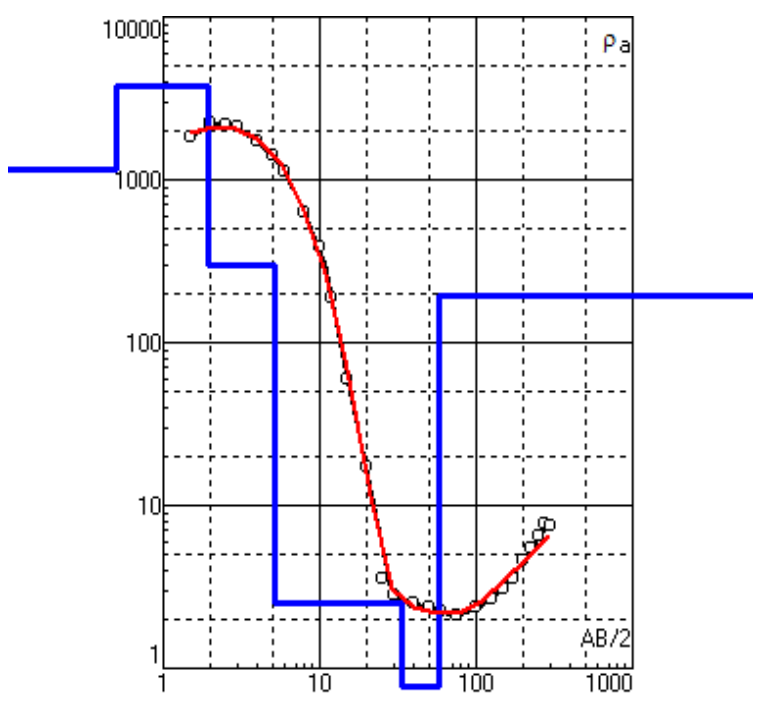

(c)

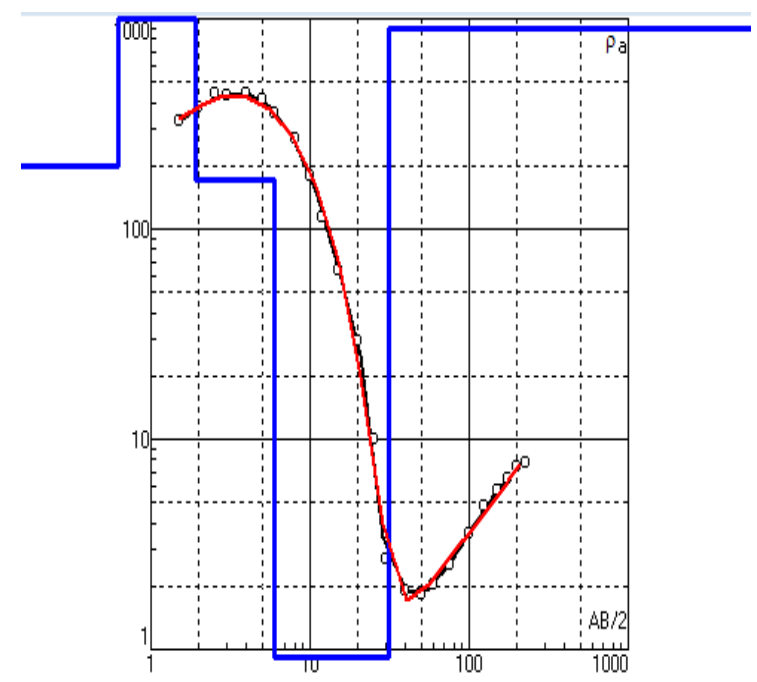

(b)

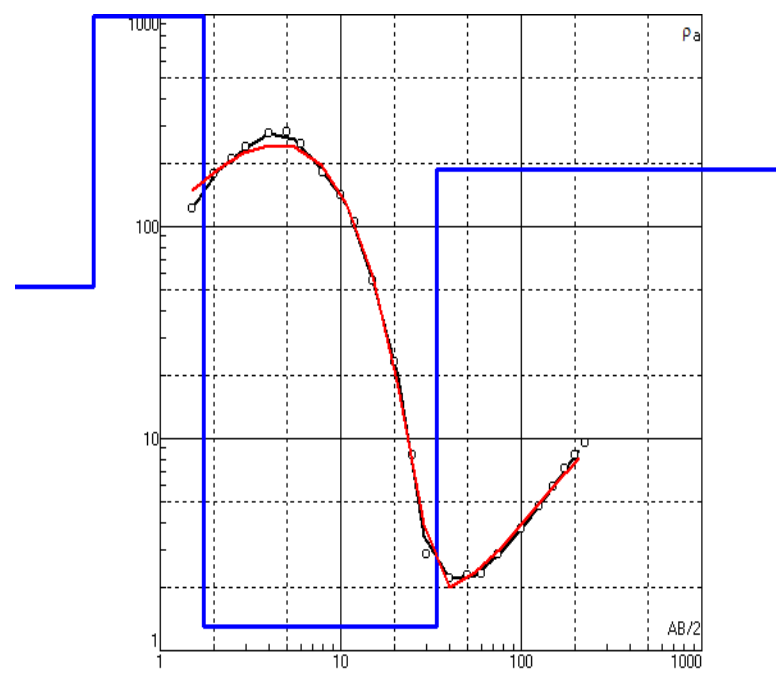

(d)

Gambar 3. Tampilan grafik 1D nilai resistivitas pada (a) titik 1, (b) titik 2, (c) titik 3 dan (d) titik 4 


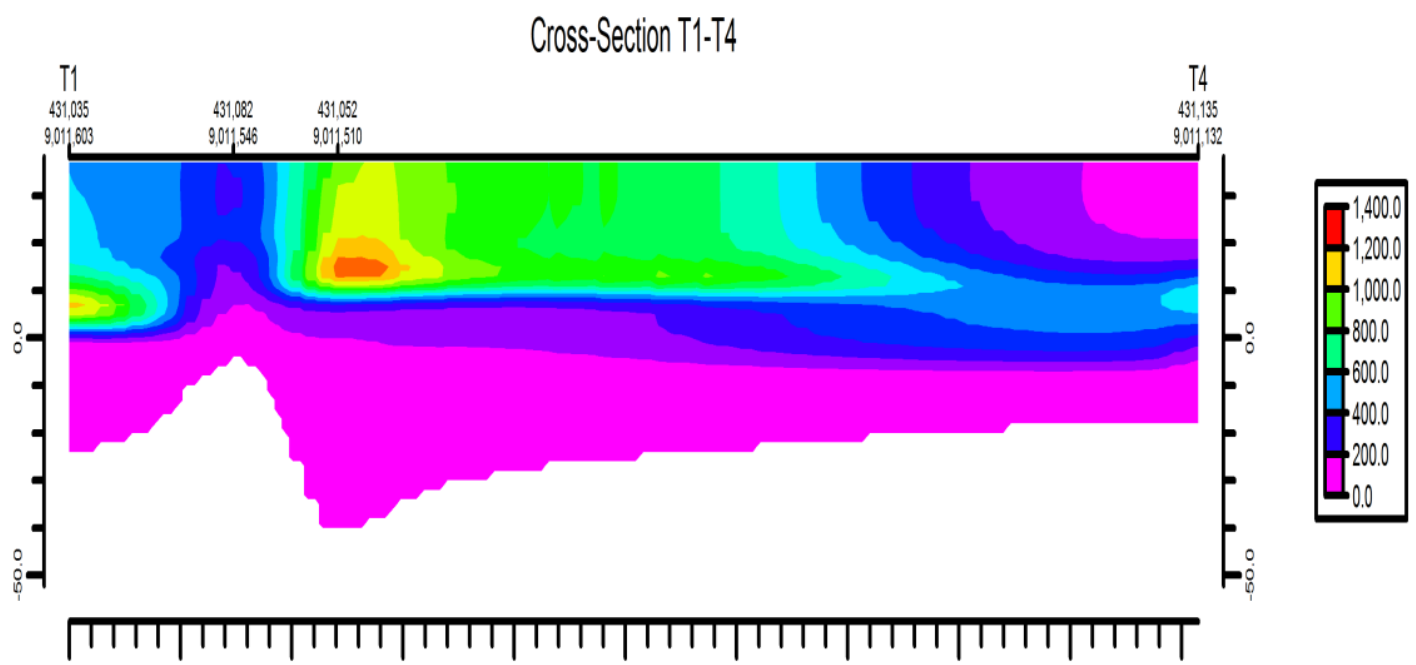

Gambar 4. Tampilan 2D Nilai Resistivitas

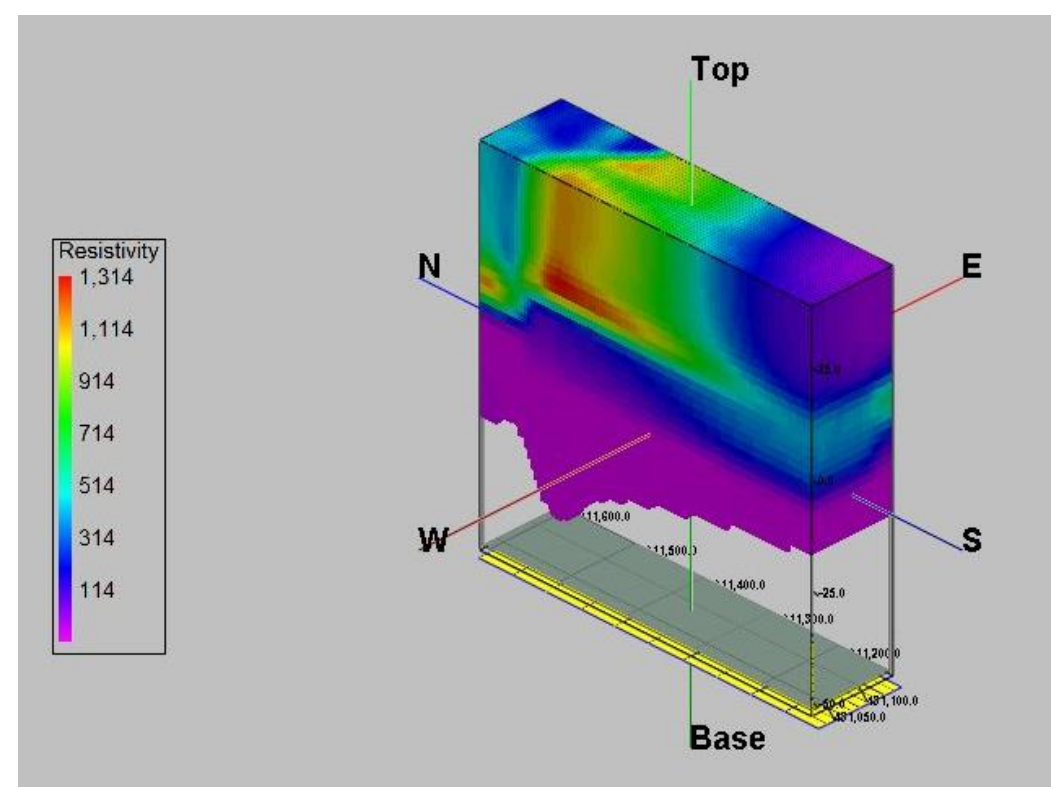

Gambar 5. Tampilan 3D nilai resistivitas

Dari pengolahan data didapat nilai resistvitas pada tiap-tiap lapisan bawah permukaan., dengan mengetahui nilai resistivitas pada tiap-tiap lapisan dapat kita tentukan jenis batuan yang terkandung pada tipa lapisan sesuai dengan table nilai resistivitas tiap-tiap batuan. Berikut jenis batuan dengan nilai resistivitas yang diperoleh nilai resistivitas, kedalaman dan lithologi. Tabel 2, 3, 4 dan 5, masingmasing menunjukkan Interpretasi lithologi pada titik pengukuran 1, 2, 3 dan 4, yang didasarkan pada nilai resistivitas dan lithologi [15].

Tabel 2. Interpretasi data titik 1

\begin{tabular}{ccccc}
\hline No & Depth-1(m) & Depth-2(m) & Resistivitas $(\Omega)$ & Lithologi \\
\hline 1 & 0 & 0.769 & 527 & Alluvium and Sands \\
2 & 0.769 & 1.85 & 3504 & Sandstones \\
3 & 1.85 & 12 & 0.813 & Clays \\
4 & 12 & 36.7 & 25.2 & Silt \\
\hline
\end{tabular}


Tabel 3. Interpretasi data titik 2

\begin{tabular}{ccccc}
\hline No & Depth-1(m) & Depth-2(m) & Resistivitas $(\boldsymbol{\Omega})$ & Lithologi \\
\hline 1 & 0 & 0.625 & 201 & Alluvium and Sands \\
2 & 0.625 & 1.8 & 998 & Sandstones \\
3 & 1.8 & 5.92 & 172 & Silt \\
4 & 5.92 & 31.2 & 0.92 & Clays \\
\hline
\end{tabular}

Tabel 4. Interpretasi data titik 3

\begin{tabular}{ccccc}
\hline No & Depth-1 $(\mathrm{m})$ & Depth-2(m) & Resistivitas $(\Omega)$ & Lithologi \\
\hline 1 & 0 & 0.5 & 1170 & Sandstones \\
2 & 0.5 & 1.92 & 3776 & Sandstones \\
3 & 1.92 & 5.17 & 301 & Alluvium and Sands \\
4 & 5.17 & 33.9 & 2.54 & Silt \\
5 & 33.9 & 58.7 & 0.78 & Clays \\
\hline
\end{tabular}

Tabel 5. Interpretasi data titik 4

\begin{tabular}{ccccc}
\hline No & Depth-1(m) & Depth-2(m) & Resistivitas $(\boldsymbol{\Omega})$ & Lithologi \\
\hline 1 & 0 & 0.521 & 63.5 & Clays \\
2 & 0.521 & 1.9 & 925 & Sandstones \\
3 & 1.9 & 34.1 & 1.3 & Silt \\
\hline
\end{tabular}

Gambar 6 menunjukkan tampilan 2 dimensi sebaran lithologi yang merupakan hasil interpretasi nilai tahanan jenis nyata yang ditampilkan pada gambar 4. Gambar 7 merupakan tampilan 3 dimensi dari sebaran lithologi yang merupakan hasil interpretasi geologi atas nilai tahanan jenis nyata yang ditampilkan pada gambar 5.

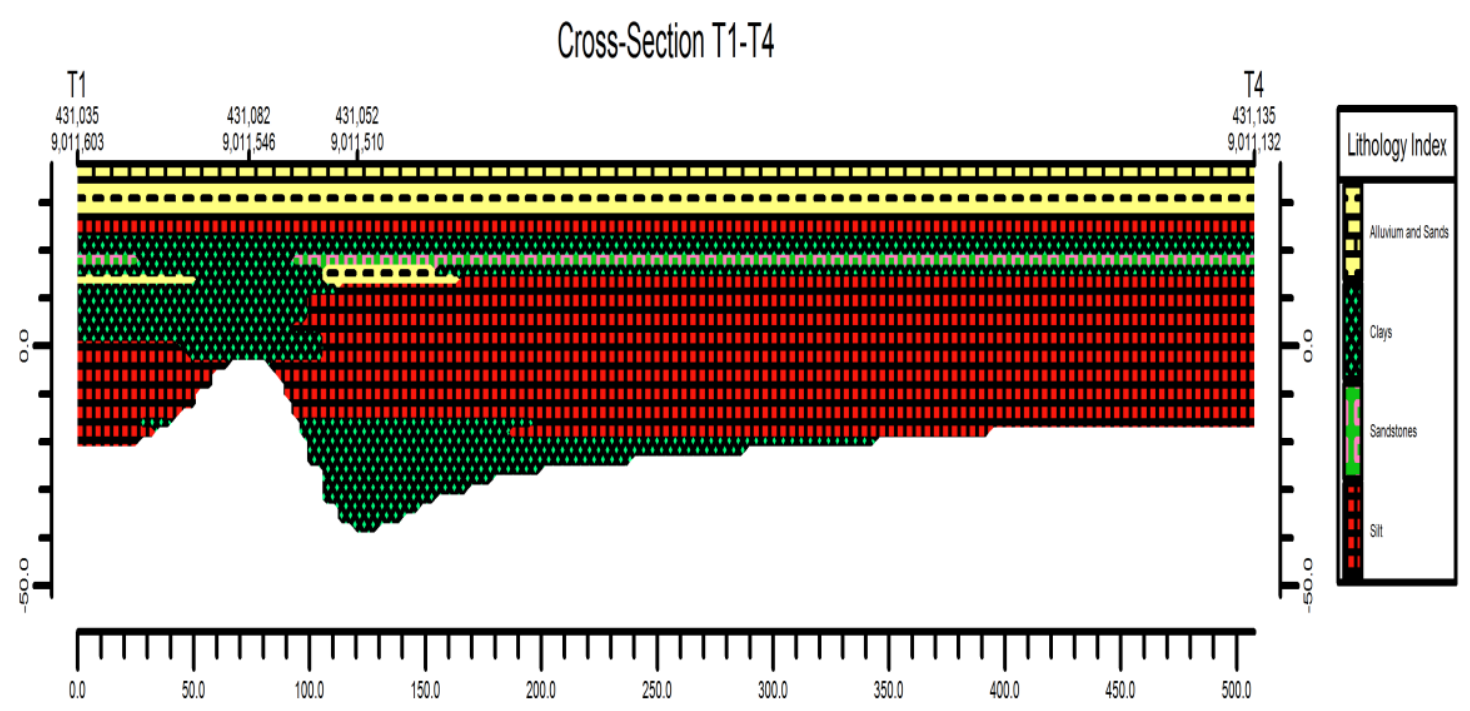

Gambar 6. Tampilan 2D sebaran lithologi 


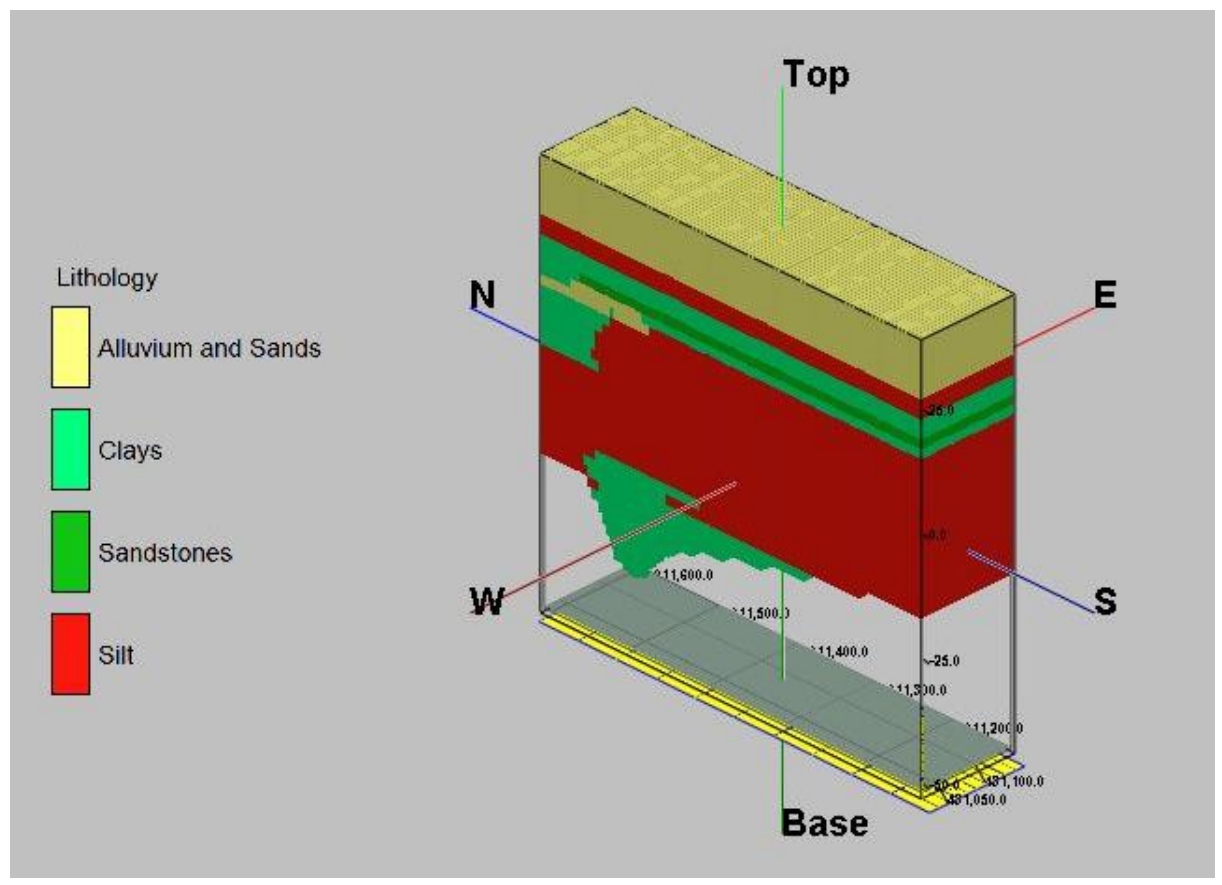

Gambar 7. Tampilan 3D sebaran lithologi

\section{KESIMPULAN}

Geomorfologi lokasi pengukuran merupakan morfologi daerah dekat pesisir pantai dengan perbukitan yang memeiliki elevasi sekitar 13-27 m. Perbukitan merupakan satuan alluvium yang didominasi oleh lempung pasiran yang berwarna coklat keabuan. Posisi satuan alluvium menempati urutan teraatas yang diperkirakan berumur kuarter sedangkan singkapan batuan dasar berupa batuan sedimen dengan jenis batu gamping.

Berdasarkan data hasil korelasi pendugaan geolistrik sebanyak 4 (empat) titik sounding menunjukkan lapisan bawah permukaan yaitu : Lapisan ke 1 berupa lempung pasiran dengan nilai resistivitas 201-527 $\Omega \mathrm{m}$. Lapisan ke-2 berupa lapisan batu pasiran dengan resistivitas $925-3504 \Omega . \mathrm{m}$. Lapisan ke-3 berupa gamping pasiran dengan resistivitas 25-63.5 $\Omega$.m dan lapisan ke-4 berupa batu gamping dengan resitivitas $0.78-25.2 \Omega$.m. Pada titik 1 kedalaman yang mengidikasikan adanya laipsan akuifer berada pada kedalaman $36,7 \mathrm{~m}$, pada titik 2 akuifer berada pada kedalaman $31,2 \mathrm{~m}$, pada titik 3 kedalaman akuifer berada pada 58,7 m, sedangkan pada titik 4 kedalaman yang mengidikasikan adanya laisan akuifer berada pada kedalaman $34,1 \mathrm{~m}$.

\section{DAFTAR PUSTAKA}

[1] Effendi, H. “Telaah Kualitas Air bagi Pengelolaan Sumber Daya dan Lingkungan Perairan”. Cetakan Kelima. Yogyakarta: Kanisius. 2003.

[2] Hasibuan, F., Susilawati, Rahmatsyah. 2013. "Studi Intrusi Air Laut Dengan Menggunakan Metode Resistivitas Listrik Konfigurasi WennerSchlumber Di Kecamatan Pantai Cermin Provinsi Sumatera Utara". Skripsi, Departemen Fisika Jl. Bioteknologi No.1 FMIPA USU Medan.

[3] Asfiannisa, Yushardi, Albertus, D. "Pendugaan Intrusi Air Laut Dalam Persiapan Pengeboran Sumur Dalam Dengan Metode Geolistrik 2d Konfigurasi Wenner Di Desa Keting Kecamatan Jombang Kabupaten Jember”. Jurnal Univeristas Jember. Vol. 3 No.4. 2015

[4] Irham, M., Refyana, T., Sugeng, W. "Pemetaan Sebaran Air Tanah Asin Pada Aquifer Dalam Di Wilayah Semarang Bawah”. Jurnal Berkala Fisika. Vol. 9, No.3. 2006. 
[5] Husni, A dan Roh, S. "Sebaran TDS, DHL, Penurunan Muka Air Tanah dan Prediksi Intrusi Air laut di Kota Tangerang Selatan”. Jurnal Teknik Sipil dan Lingkungan. Fateta IPB. 2012.

[6] Ratnakumari Y., S. N. Rai*, S. Thiagaranja dan Dewashish Kumar,. "2D Electrical Resistivity Imaging for Delineation Of Deeper Aquifers In A part Of The Chandrabhaga River Basin Nagpur District, Maharashtar, India”. Current Science. 102(1):1-9, 2012

[7] Sadjab B., As'ari dan Adey T., "Pemetaan Akuifer Air Tanah di Kecamatan Prambanan Kabupaten Sleman Daerah Istimewa Yogyakarta Dengan Metode Geolistrik Tahanan Jenis". Jurnal MIPA UNSRAT Online. 1(1): 37-44. 2012.

[8] Sedana D., As'ari dan Adey T., Pemetaan Akuifer Air Tanah Di Jalan Ringroad Kelurahan Malendeng Dengan Menggunakan Metode Geolistrik TahananJenis. Jurnal Ilmiah Sains. 15(2):1-5. 2015.

[9] Andriayanil S., Ari H. R. dan Sutanto, "Metode Geolistrik Imaging Konfigurasi Dipole-Dipole Digunakan Untuk Penelusuran Sistem Sungai Bawah Tanah Pada Kawasan Karst Di Pacitan, Jawa Timur". Jurnal EKOS AINS. 2 (1):1-9, 2010.

[10] Azhar, A., Handayani, G.,. Penerapan Metode Geolistrik Konfigurasi Schlumberger untuk Penentuan Tabanan Jenis Batubara. Bandung : ITB. 2004

[11] Derana, T. I., , "Perbandingan Interpretasi Geolistrik", Aturan Wenner dan Scblumberger, Skripsi, Jurusan Geologi Fakultas Teknik Universitas Gadjah Mada, Yogjakarta. 1981.

[12] Bisri, M,. “Aliran Air Tanah Malang“, Fakultas Teknik Universitas Brawijaya. 1991

[13] Sheriff, R E., "Encyclopedic Dictionary of Applied Geophysics, 4 th edition", SEG Tulsa, Oklahoma. 2002.

[14] Todd D.K. “Groundwater Hydrology". John Willey \& Sons. Inc. New Work, 2d.ed. 1980.

[15] Telford, W. M., Geldart, L. P. and Sheriff, R. E., , "Applied Geophysics, Second Edition", Cambridge University Press, United State of America. 1990. 